\title{
REPUBLIC OF LABOR
}



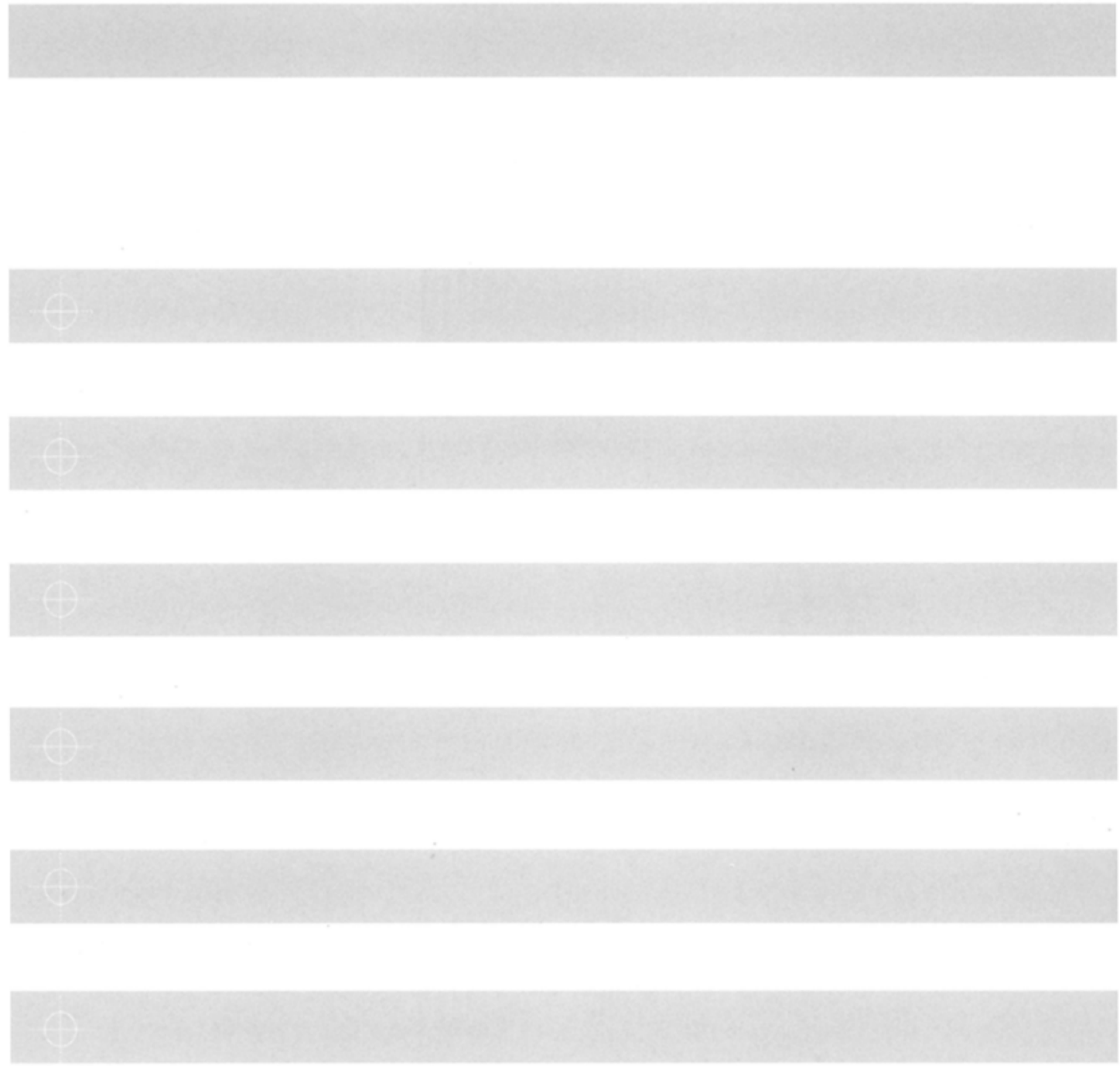


\section{REPUBLIC DF LPBDR}

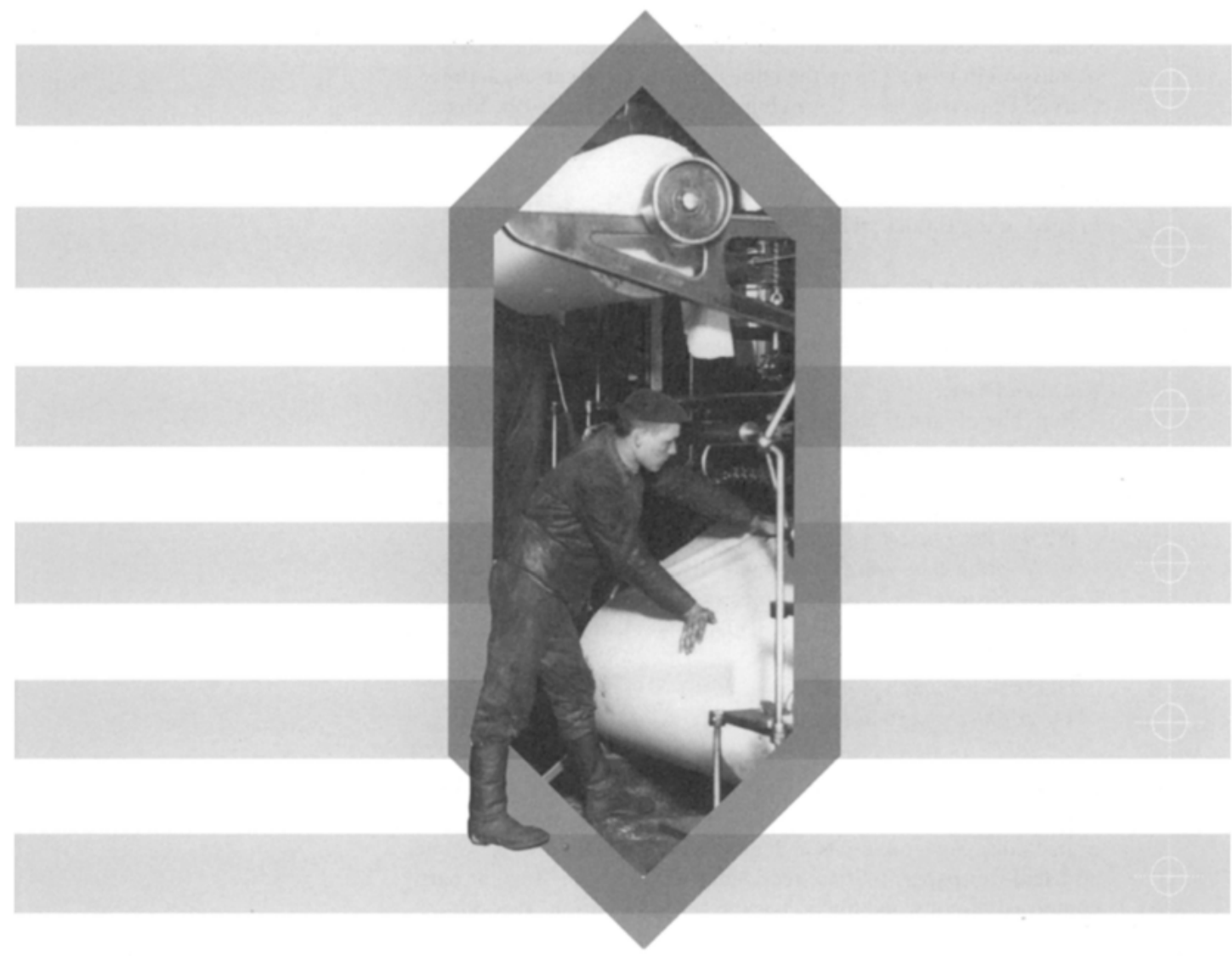

RUSSIAN PRINTERS AND SOVIET SOCIRLISM, 1918-1930 


\section{Copyright $(\odot 2005$ by Cornell University}

All rights reserved. Except for brief quotations in a review, this book, or parts thereof, must not be reproduced in any form without permission in writing from the publisher. For information, address Cornell University Press, Sage House, 5 I 2 East State Street, Ithaca, New York 14850.

First published 2005 by Cornell University Press

Printed in the United States of America

Design by Scott Levine

Library of Congress Cataloging-in-Publication Data

Koenker, Diane.

Republic of labor : Russian printers and Soviet Socialism, 1918r930/ Diane P. Koenker.

p. $\mathrm{cm}$.

Includes bibliographical references and index.

ISBN o-80I4-4308-3 (cloth : alk. paper)

I. Working class-Soviet Union-History. 2. Labor-Soviet

Union-History. 3. Printing industry-Soviet Union-History. 4. Printers-Labor unions-Soviet Union-History. 5. Industrial relations-Soviet Union-History. I. Title.

HD8 $526 . K_{59} 2005$

$33 \mathrm{I} \cdot 7^{\prime} 6862^{\prime} 094709042-\mathrm{dc22}$

2004030152

Cornell University Press strives to use environmentally responsible suppliers and materials to the fullest extent possible in the publishing of its books. Such materials include vegetable-based, low-VOC inks and acid-free papers that are recycled, totally chlorine-free, or partly composed of nonwood fibers. For further information, visit our website at www.cornellpress.cornell.edu.

Cloth printing $\quad$ 1098765432 I 
FOR HANNAH AND IN MEMORY OF EMMA 
